\title{
Existency of Women Leadership at Village Level and Its Orientation against Gender Justice (Case Studies in Banda Aceh and Aceh Besar)
}

\author{
Munawiah $^{1}$, Ernita Dewi ${ }^{2}$ \\ ${ }^{1,2}$ UIN AR-Raniry Banda Aceh. Indonesia \\ munawiah@ar-raniry.ac.id,ernita.dewi@ar-raniry.ac.id
}

\begin{abstract}
Women's leadership at the village level is a new thing for the people of Aceh today, because previously it was very rare. Becoming a leader at the village level known as a keuchik is not easy, they face many challenges and obstacles. Moreover, in initiating and running pro-women programs. However, the community has been familiar with programs that are general in nature, not looking at gender sensitive. Village development, for example, is more focused on physical construction in the form of buildings, open non-physical development such as increasing the number of women who get education, support for women's economic empowerment and also concern for increasing health awareness for women.
\end{abstract}

Keywords

leadership, women; village

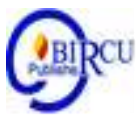

\section{Introduction}

Women leaders at the village level (gampong) who are called keuchik (village heads) in Aceh are both very rare and unique. How not to achieve a position as regional head, is not an easy thing. Becoming a member of a village consideration body is very difficult, let alone being a village leader (keuchik). However, recently an interesting phenomenon has emerged in Aceh, regarding the birth of several leaders at the village level (keuchik). An absolutely impossible reality had happened before. It is interesting to observe this phenomenon, the different tendencies in making choices to become leaders in the village, which are actually held by men but are now entrusted to women.

Becoming a leader in the bureaucracy or in the executive, legislative, and legislative fields, it seems possible to achieve Acehnese women, but to occupy a position as a keuchik, this is an impossible effort. Rejection of women's leadership is clearly seen in society, which still thinks that women are not yet worthy of occupying strategic positions in the public sphere. Women are still placed as housewives who take care of domestic problems. Although many women in the village work as farmers and traders, these jobs are not yet considered a domestic role. There is justification for women working as farmers, but there is no blessing if they serve as public leaders.

In-depth study is needed to find out about the existence of women in positions as village leaders. This fact will describe the partiality of women to programs that support efforts to improve women's welfare. The presence of women should be able to pay more attention to the needs of women, who so far have been deemed to have received less attention from male leaders. The presence of very large village funds that can be managed with high creativity by the community should be a land for the development of women's potential which in the end can improve the economy and life women together with men. 


\section{Review of Literature}

\section{Definition and Theory of Leadership}

Leadership can be defined as the activity of influencing 'subordinates' or others to carry out their duties, or to achieve the mission and vision. Leadership is the ability to bring the organization more to develop, motivate and coordinate the people in the group in order to achieve common goals in work. There are several characteristics that must be applied by a leader in carrying out his leadership, including; confident, ethical, disciplined and competent in carrying out his jobs.

Leadership can be defined as a process of directing and giving influence to the activities of a group of members who are related to their duties (Stoner, 1992: 114). According to Gorton et al., Leadership is a characteristic of leaders in influencing subordinates to achieve organizational goals. The success of leadership is partly determined by the ability of leaders to develop their organizational culture. (Arif, 2019).

The leadership is a process that affects organized groups which direct to achieve organizational objectives as the appropriate base to measure leadership construction. (Sabri et al., 2011) used eight indicators to measure leadership construction which called Leadership Effectiveness Index such as: competence, fair treatment, work climate, superior ideas, attention, subordinate involvement, cooperation, and opportunity to interact. Organizational communication is satisfaction of organizational member toward several communication aspects occurs within organization. Variable indicator of organizational communication would include organization perspective, personal feedback, organizational integration, direct superior communication, communication climate, horizontal communication, media quality and subordinate communication. (Syakur, A. et al. 2020)

Humans are multi-dimensional creatures that have their own uniqueness and clearly have differences with other creatures. Humans have a noble personality and are able to behave properly in accordance with the guidance of the Koran and Hadith. As beings who have the ability to think, act, and are able to do something well, it makes no difference when someone becomes a leader, both as a man and as a woman. Although there is still an opinion in society that women are not worthy of being leaders in the public sphere, in fact this is not a debate if someone returns to the fact that humans are created with the same abilities between men and women, besides there are natural differences. However, this cannot be a cover for not giving women access to become public leaders.

Being a leader is certainly not easy, if someone has a leadership spirit, he will try his best to become a good leader. There are several duties of a leader to foster his subordinates, namely; education, a leader must be able to educate colleagues or subordinates. Discipline, a leader must exemplify an example and must uphold the value of this discipline because it is to arouse other colleagues to carry out every activity with discipline. Advice, which is to provide advice and suggestions from difficulties in work. The last thing is loyalty, the leader must be able to arouse the spirit of loyalty from other colleagues in working in order to create good cooperation.

Talking about leadership, women's leadership rights are the top concern for many people. Racism and discrimination by society for women as leaders have been done for a long time. Until now, women are still struggling to achieve gender equality. Actually, all human beings have the right and authority to be leaders if they are able. However, the existence of gender differences between women and men means that there are differences in leadership styles. Women have a way and style of leading that tends to be different from men. It is rarely known that women actually have the skills and strengths to work with 
other people. In matters of leadership, women are actually more participatory and democratic.

After discussing the notion of leadership, this paper also refers to leadership theory. This leadership theory describes how a person becomes a leader and how a leader emerges. Broadly speaking, there are 3 kinds of leadership theory. Among them; In trait theory, there is some research conducted to identify consistent traits in leadership. These characteristics are such as self-confidence, fairness, love to protect, creative and innovative and also have knowledge that is relevant to their work.

The second is behavior theory. There are two basic categories that describe most leader behavior; the structure of initiative and consideration. In an effort to advance and develop the work of the leader must understand the behavior of each of his colleagues and employees in his work environment. The leader's behavior also determines how his subordinates behave. Therefore, a leader is required to behave well, be polite, respect the ideas of his subordinates and trust each other.

Lastly is environmental theory. This theory states that the birth of leaders is the result of time, circumstances and place. This theory has an influence on a person's leadership style. This theory explains about a leader in carrying out his job in accordance with the guidance, conditions and situations of the era.

Along with the times, the position of women in leadership also shows extraordinary progress. Several strategic positions in government have been filled by women. Likewise in terms of political leadership such as being president, governor, regent and mayor. Another interesting phenomenon is the emergence of women's leadership at the village level (gampong), especially in Aceh. This position was impossible to obtain before, because the position of village head tended to be understood as a position that could only be held by men. However, currently in the 2018 era, there are several female village heads that have succeeded in holding positions that were previously still very foreign.

\section{Results and Discussion}

\subsection{Women's Participation in Gampong: Role and Innovation}

The participation of women at the gampong level still seems to be not optimal, this is indicated by the fact that women have not been actively involved in solving problems, or in deliberations on the use of village funds. Moreover, at this time the village has received village funds, which funds are intended entirely for the village, so that it is managed creatively and innovatively, so that a village can achieve economic prosperity and stability. In this field of village development, of course women's participation is highly prioritized, so that they can provide the best contribution to village development. The desire to increase women's participation in the village realm is a priority, not just being present at women's activities such as PKK and Posyandu. The lack of women's involvement in village development is a serious problem, especially the very few women who served as village level leaders. When these positions are given to women, and become village leaders, women's involvement can be increased or not, this is also homework for all related elements.

The low involvement of women certainly invites a curiosity to learn more about the position of women in village institutions, especially regarding the role of women in decision making at the village level. With one goal answered how the position, participation, and role of women in decision making on village development in Indonesia, both at the planning, implementation, and monitoring and evaluation stages of village development. This article is here to answer the position of women as leaders in decision-making to actively involve women in village development activities and other pro-women's programs. 
Regarding the topic of women and decision making, there were several discussions. Like Hernita Sahban's work entitled The Role of Women's Leadership in Decision Making in Indonesia. This paper explains in general about women's leadership in decision-making in Indonesia, the focus of the research is not on institutions and village development. The same thing is in Agusnawati's work entitled "The Role of Women in Decision Making in Community Managers of the Kemiri Forest in Mario Pulana". This journal explains about community decision making in the management of candlenut forests in Mario Pulana and its surroundings which are non-formal in nature and have become a habit that is mandatory for the flesh. However, this research study did not focus on village development.

Women are able to provide the best for their village, for example the innovation that was born by a female member of Tambo Baroe village, Aceh Besar, according to the statement of the local village head, that the mother of a Tuha Peut member has developed small and medium enterprises in their village, in the form of making a traditional Aceh cake, also makes beef jerky which sales have reached the city of Banda Aceh. This mother, a member of tuha peut village, has employed several other mothers in her business of making cakes and beef jerky. This can improve the community economy, especially women in Tamboe Baroe village. Not only able to develop her business, this tuha peut member mother is also able to provide her smart thoughts in solving women's problems in Tambo Baroe village.

If women are given the opportunity and take part in village development, there will be many innovations and creative thoughts that they can provide, one of which is in the village of Tambo Baroe. Keuchik in the local village said that he really cares about the presence of women in the village level public domain, because women have extraordinary abilities if they are able to be optimized, with the help of village officials such as the keuchik and his staff. However, this really depends on the situation and conditions of the village, there are those who do not really care or are unable to maximize the potential of women. The point is that women have the potential and innovation, it remains how the opportunity is given to them.

\subsection{Pave the Way for Women's Participation}

The role of the village is so big in today's development, of course, it must be addressed in such a way so that the potential of the village is not just lost and that economic empowerment can be carried out as much as possible. The participation of women in village development cannot be ignored, with the number of women reaching more than fifty percent of the village population, of course it will have a significant added value if the existence of women can be maximized. Even some villages that have recorded achievements as model villages cannot be separated from the role of women in them. Call it the village of Tambo Baroe in Aceh Besar, this village has recorded a brilliant achievement by becoming an accomplished village in Aceh Province. Some of the achievements made include the empowerment of the village economy in the form of beef jerky products, traditional cakes, and also the village convection business.

The local village keuchik stated that the role of women was very important and dominant in increasing the village's original income, especially for the economic empowerment of the community. Women have high morale, are very painstaking and are always looking for new innovations for the development of the small businesses they have initiated in the village of Tambo Baroe. The success of Tambo Baroe Village in achieving the achievement as the best gampong is a concrete manifestation of the presence of women to contribute together with men to contribute to village development. 
One female keuchik who leads the village of Miruek Taman Aceh Besar said that she wanted her community to be economically independent. The initial cause of him being asked by the community to become a keuchik (village head) was due to stagnation in the management of BUMG (Village-Owned Enterprises). BUMG in the village does not develop as it should, for example BUMG money is bought for a tractor machine, then rented out, but the rental proceeds are not efficient, they are not even able to contribute to be used as village savings. Ironically, the tractor finally broke down, and the village assets were lost. Likewise with the rental of a house, but when there is a repair, it is not taken from the rent, but house repairs are borne by the village fund. This then prompted the community to ask the elected keuchik mother to be willing to become the next village leader. Another reason is that the keuchik mother, who is an economics graduate, has succeeded in building a cooperative which later developed into a BPR (Bank Pengkreditan Rakyat), and now even has several branches.

The existence of this female keuchik mother is also supported by the role of her parents, who have served as keuchik for twenty-one years. Besides that, the keuchik mother is a person who is already well-off economically. One of the siblings has enough money and often holds big events in their village. Also fostering the village mothers and fathers in social and religious activities. The keuchik mother said that it was the community that pushed her to become a leader, even though at first the keuchik mother did not want to, plus her husband initially disagreed with her running as a keuchik. Then about five people came from the female representative to the keuchik mother and asked her to be willing to be nominated.

Support for the nomination of the mother keuchik has also received approval from local clerics, who are highly respected and respected by the residents. Even the local cleric immediately asked the keuchik's mother to be willing to become a keuchik. Even though there are many religious leaders, other scholars are unwilling to provide support to women leaders. It is very different from the condition of this keuchik mother, who was actually willing to be asked directly by the local cleric.

Another female keuchik in Cot Mesjid village, Lueng Bata sub-district, also received full support from the Lueng Bata community. As the first female keuchik in the village, of course it was not easy for her to occupy this position, but the local community convinced her to become a keuchik, and the support was not divided, all people agreed to vote for her. This is evidenced by the election results, where this keuchik mother managed to shift the other two male candidates, with the votes that she won. This election can be said to be tough because there are two rivals from the male side, of course it is not easy for women to win. Support from women is also very high for this chosen keuchik mother.

The success achieved by the Keuchik mother of the village of Cot Mesjid was also influenced by the support of her husband who previously served as Acting Keuchik. Initially the husband disagreed with his wife running as a keuchik, but because her husband could not run again, because her husband was not a local resident, the wife ran instead. In addition, his desire to run for office was also influenced by the existence of a neighboring village where in the election for the keuchik there was a female candidate, even though the candidate was not elected. Besides that, the community, especially women, gave full support to prospective keuchik mothers, so that they were willing to run, and the result was that the keuchik mothers were elected in the middle of quite a tough fight. 


\subsection{Contributions Made by Female Leaders}

The present era is marked by the presence of women who, by regulation, allow themselves to be actively involved in social, economic, and political activities. Therefore, the presence of women on every line is no longer a strange thing, as in previous decades, where women were only involved in domestic factors, and were deemed unfit to be in the public sphere.

Development is born because of the involvement of human roles as the subject of development. Society as a collection of human groups has an important position and role in determining development, both from the local level to the global scope. From several studies on the role (role), it is mentioned as a dynamic aspect of position (status). As the quote from Narwoko's opinion in Anggelia which analogizes: Role and position are like a person has exercised their rights and carried out their obligations in accordance with their position, then that person has carried out a role. The two cannot be separated because one another is interdependent, meaning that there is no role without status and no status without a role. As is the position, all people can also have various things, the role that comes from the social sphere of his life. This also means that this role determines what he does for the community and what opportunities the community gives him.

The role inherent in a person must be distinguished from the position or place in social life. A person's position in society (social-position) is a static element that indicates an individual's place in a community organization. The role of society in development shows as a form of participation. Women as an important element in society certainly have the same rights and opportunities to be involved in development. Women's participation in development is very important, considering that development will also accommodate various services and needs of women. So apart from being the object of development, women also have to play a role as the subject of development.

Women as one of the elements that are encouraged to participate in development are often faced with policies and decisions. Its role in determining decisions is also very important in determining the direction of development. What is meant by the meaning of a decision is a choice, which is a choice of two, three, four or more possibilities. Although ordinary decisions are said to be the same as choices, there are important differences between the two. Mc Kenzei as quoted in Hernita, explained that, "a decision is a real choice because choice is defined as a choice about goals including choices about how to achieve that goal, whether at the individual or collective level".

The female keuchik testified that they also wish to support programs based on women's needs. Even though the Vision and Mission of the village of Miruek Taman has not yet been seen concretely about pro-women programs. Only in a number of aspects that are visible to be special programs for women such as the PKK and Posyandu programs, while other village development programs are not visible. However, according to Keuchik Miruk Taman, she is very supportive of the women's economy by changing the BUMG system that optimizes women's management. Then the keuchik mother also encouraged batik training activities for women. In the field of education, the keuchik mother has sought an operational permit for kindergarten schools in the village.

Another program is the cleanliness of the village that the keuchik women really prioritize, namely the waste management program. According to the keuchik's mother, usually the cost for garbage collection is taken every month, but in reality, when the citation was not paid. Then another solution was taken, by means of daily quotations. When the waste is collected, at that time a payment is made. This is a more effective way to increase village funds, after being paid wages for the people who work. 
The keuchik of the village of Cot Mesjid also provided support for education, by initiating a Village Kindergarten school. Besides that, the keuchik mother also conducts public speaking training for PAUD teachers, so it is hoped that they will have the courage to come forward and give their opinions, especially for suggestions for village development. Selected keuchik mothers have designed many programs to run, and these programs give great attention to women. There are many programs for women but they have not been running well, but because of the Covid-19 pandemic, these programs cannot be implemented.

Keuchik's mother is also eager to create a child-friendly village, as this program is a big program for the city of Banda Aceh. Child-friendly villages strive to make children more creative and innovative, and not only neglected by cellphones that keep children busy playing games. The time available is spent playing for uselessly. The keuchik mother also tries to make the recitation more alive for mothers both in the mosque and at home. The purpose of this recitation is so that mothers can gather in noble assemblies, learn about religious knowledge, so that it is useful for their lives, in addition to establishing friendship between them. Because they will meet when there is a recitation, and can share about various things. This event also allows the keuchik mother to access all information and things that occur within the community under her leadership.

The programs that have been and will be carried out by the keuchik mother, not all of them have the support of the residents, there are also a handful of villagers who say that not all mother keuchik programs are new programs, because these programs have already been launched and even run by the previous keuchik There is nothing new about leadership now, because these are old programs. However, the researchers saw that the keuchik mother had tried to build her community well, if there was still a shortage, then all residents had to support and help the keuchik mother to be better at leading her village.

In the process of carrying out her duties leading the village, the keuchik mother of the village of Cot Mesjid was greatly assisted by her husband, especially since her husband had experience as Acting Keuchik before he was elected. This is different from the Keuchik woman in Miruk Taman village, in working to optimize her abilities, and also asking for opinions from her staff, because the husband of the keuchik mother has no direct experience in running the village government.

\section{Conclusion}

The phenomenon of the emergence of a female keuchik in Aceh is strongly influenced by the existence of the keuchik which is supported by economic stability, the family factor that has influence and the existence of a husband who was first known by the community. This means that the path for someone to become a keuchik in Aceh is not easy, especially women. There is a desire to run for office but if it is not supported by the community, especially if the candidate is not an influential person, does not have economic stability, and is not from a family who is a community leader, it will be very difficult for the woman to become a leader.

When a woman becomes a leader, of course there are many challenges and obstacles faced by people, especially from the community who did not support her when she was running. Unlike a candidate who is fully supported by the community, this will make it easier for him to carry out his programs. But when women lead there is a large space to run women-based programs. However, this condition cannot be fully implemented, because the programs that have taken root in the community are more general programs and are not specifically for women. This makes women leaders unable to fully initiate or run gendersensitive programs. 


\section{References}

Agusnawati. (2006). Peran Kaum Perempuan dalam Pengambilan Keputusan Pada Masyarakat Pengelola Hutan Kemiri di Mario Pulana, Cifor, diakses melalui: http://www.cifor.org

Arif, S. (2019). Influence of Leadership, Organizational Culture, Work Motivation, and Job Satisfaction of Performance Principles of Senior High School in Medan City. Budapest International Research and Critics Institute-Journal (BIRCI-Journal). P. 239-254

Cahyaningsih, Ica Putri. Et al. (2020). Peran Kepemimpinan Wanita di Era Modern, AlYasini: Jurnal Kajian dan Penelitian dalam Bidang Keislaman dan Pendidikan, Universitas Muhammadiyah Malang, Vol. 5, No. 1.

Chairunnisa, Connie.(2017). Manajemen Pendidikan dalam Multi perfpektif, (Depok: PT. Rajagrafindo Persada, 2016. Lihat juga: Irham Fahmi, Manajemen Kepemimpinan Teori dan Aplikasi (Bandung: ALFABETA).

Ernita Dewi. (2015). Konsep Manusia Ideal Dalam Perspektif Suhrawardi al-Maqtul, Jurnal Subtansia, Fakultas Ushuluddin dan Filsafat UIN Ar-Raniry,Volume 17 Nomor 1, April

Manembu, Angelia E. (2017). Peranan Perempuan dalam Pembangunan Masyarakat Desa (Suatu Studi di Desa Maumbi Kecamatan Kalawat Kabupaten Minahasa Utara) Manado: Jurnal Politico Vol. 6.

Nurhalimah, Andi. (2018). Pastisipasi Kaum Perempuan Dalam Perencanaan Pengelolaan Dana Desa. Batam: Jurnal Administrasi Negara UMRAH.

Rivai, Veithzal. et al. (2014) Pemimpin dan Kepemimpinan dalam Organisasi (Jakarta: PT RajaGrafindo).

Sabhan, Hernita.(2016) Peran Kepemimpinan Perempuan dalam Pengambilan Keputusan di Indonesia, Makassar: Jurnal Ilmiah BONGAYA.

Syahril, Sulthon. (2019). Teori-teori Kepemimpinan, dalam Jurnal Ri'ayah, Universitas Islam Negeri Raden Intan Lampung, Vol. 04, No. 02.

Syakur, A. et al. (2020). Sustainability of Communication, Organizational Culture, Cooperation, Trust and Leadership Style for Lecturer Commitments in Higher Education. Budapest International Research and Critics Institute-Journal (BIRCIJournal). P. 1325-1335.

Triana, Sofiani. (2009). Membuka Ruang Partisipasi Perempuan dalam Pembangunan, Pekalongan: Jurnal Muwazah.

Widayati. (2015). Endang. Partisipasi Perempuan dalam Kelembagaan Desa (Studi Kasus Pada BKM Desa Umbulmartani dan Jogotirto), Yogyakarta: Universitas PGRI.

Yudiaatmaja, Fridayana. (2013). Kepemimpinan: Konsep, Teori dan Karakternya, dalam Jurnal Media Komunikasi FIS, Universitas Pendidikan Ganesha, Vol. 12, No. 2. Lihat juga: Viethzal Rivai, dkk dalam Pemimpin dan Kepemimpinan dalam organisasi, 7. 